\title{
Islamic Practice among Polytechnic Ungku Omar Students
}

\author{
Fariza Md Sham ${ }^{1}$, Siti Rugayah Hj Tibek $^{2} \&$ Seri Kartini Juraimi ${ }^{3}$ \\ ${ }^{1}$ Faculty of Islamic Studies, \& Institute of Islam Hadhari, The National University of Malaysia, Malaysia \\ ${ }^{2}$ Faculty of Leadership \& Management, Islamic Science University of Malaysia, Malaysia \\ ${ }^{3}$ Polytechnic Ungku Omar, Ipoh \\ Correspondence: Fariza Md Sham, Faculty of Islamic Studies, \& Institute of Islam Hadhari, The National \\ University of Malaysia, Malaysia. E-mail: farisham@ukm.edu.my
}

Received: November 2, 2014

doi:10.5539/ass.v11n24p39
Accepted: July 1, 2015 Online Published: August 18, 2015

URL: http://dx.doi.org/10.5539/ass.v11n24p39

\begin{abstract}
The purpose of Islamic education is to impart knowledge of Islamic teachings for students to practise in their daily lives. Islamic Education is a compulsory course for all Polytechnic students in Malaysia. However, there has not been any study on its effectiveness on the Islamic practice of students in their daily lives. Hence, this research is to measure the effectiveness of implementing this course on the Islamic practice among students of one of the polytechnics in Malaysia, Ungku Omar Polytechnic (PUO), Ipoh, Malaysia. The purpose of this research is to study the level of Islamic practice among students in terms of aqidah (belief), ibadah (worship) and akhlak (moral/ character). This research is a study survey. The research instrument used to measure the level of Islamic practice among Muslim students is the Islamic Practice Instrument (IPI-Fariza). 60 male and 40 female students are selected as research respondents. Data obtained through questionnaire forms is analysed using SPSS software and research findings are explained using descriptive statistics displayed in mean scores. The Alpha Cronbach reliability value for the whole of the question items in the questionnaire is high, that is, 0.923. Research outcome shows that the level of Islamic practice among respondents is high in all aspects, that is aqidah 100.0 percent, ibadah 94.0 percent and akhlak 96.0 percent. In conclusion, overall research findings show that the level of Islamic practice among students in PUO is high. This shows that the Islamic Education course taught has a favourable effect on Islamic practice among students of Ungku Omar Polytechnic (PUO), Ipoh, Malaysia.
\end{abstract}

Keywords: practice, Aqidah (Belief), Ibadah (Worship), Akhlak (Morals/ Character), Islamic Education

\section{Introduction}

Islamic education implemented in Malaysia aims to impart knowledge to students on how to practise Islamic teachings in daily life. The concept of Islamic practice has three components, that is, aqidah (belief), ibadah (worship) and akhlak (morals/ character). These three components are closely related as a sign of a Muslim's faith and servitude to God (Sabiq, 1992). The course Islamic Education which covers the three components is compulsory on all Muslim students at Politeknik Ungku Omar (PUO), Ipoh. The purpose of this course is to teach students how to apply Islamic knowledge in their daily lives. One of the methods used to measure the effectiveness of this course is by studying the level of Islamic practice among students. This article displays the outcome of research conducted on Islamic practice among students in PUO, Ipoh. This research studies the level of Islamic practice among Muslim students in this institution in terms of aqidah (belief), ibadah (worship) and akhlak (morals/ character).

Islamic education is a physical, spiritual and mental guidance or process towards the formation of a good Muslim character (Mustafa, 1999). According to Zakiah Daradjat (1992), Islamic education is the formation of a Muslim character through belief and practice. The course is one of the living subjects which encompass all aspects of human life. It is not just a compulsory subject but more importantly, it aims to develop a humane personality. Religious/Islamic education is very important in teaching children to distinguish between what is beneficial and what is harmful (Salasiah et al., 2014). Based on present reality, students do not fully practise theory learnt in their daily lives. According to Mohd @ Mohamed (2000) students still fail to translate religious theory learnt and understood into a practical way of life. In fact, some of the students avoid religious teachings while appreciation of Islam among students is increasingly lax (Fauzi, 2003). 
Some research conducted at the level of higher learning institutions (IPT) find that Islamic practice among students is still at a low level, such as research done by Mohd @ Mohamed (2000) on Islamic practice among students of private institutions of higher learning. Research done by Ahmad Diniah (1995), finds that trainees lack appreciation of moral values towards Allah s.w.t., themselves and society. Research by Alias (2010) in a polytechnic finds that aqidah of students are at a high level, but practice levels of ibadah and akhlak are only at average level. This shows that the effectiveness of Islamic Education has not reached the desired high level of effectiveness in practice. Research by Shamshuddin (1990) finds that achievement of the objectives of Islamic Education at PUO is not yet satisfactory. His research finds that 58 percent of respondents lack interest in the Islamic Education course and that only 62 percent of them have mastered the basic Islamic knowledge. A variety of new methods and modules have been introduced in the course at PUO. In efforts to strengthen the course, specifically to guide PUO students in the practical aspect, research needs to be done from time to time to determine the extent of Islamic practice among the students. In this regard, Ahmad Munawar (2009) states that the subject Islamic Education needs constant upgrading from time to time so that students are motivated to make Islam a practical way of life.

\section{Concept of Islamic Practice}

The practice of Islam is a responsibility given by Allah s.w.t to every Muslim and it must be fulfilled by every Muslim without any doubt. Human beings are creatures of Allah and it is the best creation of all and when they are first born they are purely born without any sin. As a human being, they are created and equip with various senses, having brain to think reason out what's right and wrong. With these, Islam has come upon them to perform their duties as servants to their creator and be a Khalifah of Allah in the surface of the earth. Their responsibility to Allah is clearly stated in the Qur'an in Surah al-Zariyat verse 56.

Means: I have only created jinns and men, that they may serve Me.

In practice the teachings of Islam, there are three aspects or components that need to be understood and at the same time practiced by the Muslim which is aqidah, ibadah and akhlak.

In Islam, aqidah is the most important aspect in all practice. This is stressed by al-Ghazali (2000:198) who stated that aqidah or belief are the most honorable or noble matters in Islamic teachings and the source of all goodness. Aqidah means complete belief or faith in the truth or reality, without doubt, as prescribed by Islam (al-Jaza'iri, non date). This is the reason why we need to measure the level of aqidah practice among muslim because aqidah is very important for Muslims.

In the context of this study, ibadah practice highlighted as obligatory in the daily life of a Muslim student include the obligatory of five times daily prayers, fasting in Ramadan, paying zakah, cleansing of impurities and covering the aurat. The purpose of performing specific ibadah in Islam such as prayers (solat), reading al-Quran, fasting in Ramadan, paying zakah and performing $H a j$ are not merely requirements of Islamic teachings, but also to improve moral character and behavior. According to Abdul Karim Zaydan (1972), each action done by a Muslim in his life in compliance with Allah's command is considered as ibadah and purification of his or her soul

Akhlak is closely linked with implementation of the ibadah aspect because a good akhlak will lead to doing good and leaving that which is prohibited by Allah.s.w.t. (Ibn Taimiyyah, 1981; Zakaria, 2001). This discussion explains that akhlak is among that which cannot be neglected in the life of a student. The Prophet pbuh was deeply concerned about the importance of an honorable character as stated in a hadith:

"There is nothing which outweighs more on a weighing scale than an honorable character and one with such a character may achieve the rank of he who fasts and prays " (Hadith riwayat al-Tirmidhi, Kitab (23) al-Bir wa al-Silah, Bab (60) ma Ja'a fi al-Husn al-Khuluq).

Faith in Islam (iman) would not be complete without aqidah,ibadah and akhlak. Either strong or weak a person's faith can also be measured or known from his akhlak.With strong iman also will eventually produce a strong believer with good aqidah,ibadah and akhlak.This because of the strong faith expressed human worship and virtuous and so otherwise.

Iman is the basic foundation needed in one soul and with iman comes the good practices of Islam. Akhlak comes from one thought and needs. Doing a perfect and truthfully practice of Islam, we need a good akhlaq. At the same time having a good practice of Islam, keep one's akhlaq in agood level as prayers (solat), fasting cans make people more devoted (taqwa) while zakah can help purify one soul and body (Jawiah et al., 2008).

The discussion above clearly shows that there is the relationship between aqidah, ibadah and akhlak. These three components also affecting each other in determining the extent of one's to its creator (Allah s.w.t). It is 
correct and appropriate to assess one belief in the teaching of Islam through the aspects of aqidah, ibadah and akhlak.Religious/Islamic practice can strengthen the persoanlity and spirituality of students (Fariza, 2015).

Hence, this research is conducted to study the effectiveness of the Islamic Education course being implemented in the Polytechnic by measuring the level of Islamic practice in the three aspects of aqidah (belief), ibadah (worship) and akhlak (morals/character).

\section{Research Design}

This research is designed as a study at Politeknik Ungku Omar (PUO), Ipoh, Malaysia. The polytechnic is selected as research location because it is the first polytechnic in Malaysia. Hence, it has the benefit of experience and older teaching system in comparison to other polytechnics in Malaysia.

\section{Participants}

Research participants are 100 students of semester II, Department of Civil Engineering, PUO, Ipoh. This group is selected because they have followed the Islamic Education course for 2 semesters. Selection is by convenience sampling.

\section{Measuring Instrument}

The research instrument to measure the level of Islamic practice is the Islamic Practice Instrument (IPI-Fariza) produced by a research group panel of the Faculty of Islamic Studies (FPI), National University of Malaysia (Fariza, 2011). IPI-Fariza is formed to specifically measure the level of Islamic practice among Muslim adolescents. It consists of 3 components, aqidah (belief), ibadah (worship) and akhlak (morals/ character) each containing 30 items. Each item has a Likert scale with a selection of answers ranging between $1=$ strongly disagree to $5=$ strongly agree. IPI-Fariza has been modified to suit research respondents by selecting 45 suitable items, that is of 15 items for each of the three components.

A pilot study was conducted on 30 Muslim students in Semester II, Department of Mechanical Engineering, PUO, Ipoh with the purpose of testing the suitability of the measuring instrument on selected respondents. The Alpha Cronbach reliability value for aqidah practice was 0.801 , ibadah practice was 0.890 and akhlak practice was 0.821 . The Alpha Cronbach reliability value for the whole of the question items in the questionnaire was high at 0.923 . Thus, the reliability of this research instrument is validated for its applicability to this research.

\section{Data Analysis}

Data obtained from questionnaires is analysed using SPSS software and study findings explained by using descriptive statistics in the form of mean scores. To determine the level of Islamic practice in terms of aqidah, ibadah dan akhlak and the overall level of Islamic practice among respondents, three levels are categorised at high, average and low. Table 1 below displays the score range of categories in the level of student Islamic practice.

Table 1. Determination of Islamic Practice Level

\begin{tabular}{ccc}
\hline Component & Score Range & Level \\
\hline Aqidah, Ibadah and Akhlak & $55-75$ & High \\
& $35-54$ & Average \\
Overall & $15-34$ & Low \\
& $166-225$ & High \\
& $106-165$ & Average \\
& $45-105$ & Low \\
\hline
\end{tabular}

Source: Questionnaire 2011

\section{Result}

The research outcome obtained is described in three components of Islamic practice, in terms of aqidah, ibadah and akhlak. The research outcome is as follows:

\section{Respondent's Aqidah Practice}

Analysis of answers given by respondents based on items provided shows that the highest mean score is 5.00 as 
the maximum mean score whereas the lowest mean score is 4.22 . Overall, all items have a mean score $>4.00$ which shows the mean score of each item is at a high level.

Table 2. Respondent's Aqidah Practice

\begin{tabular}{|c|c|c|}
\hline No. & Item & Mean \\
\hline 1 & I believe that Allah s.w.t. exists. & 5.00 \\
\hline 2 & I am able to declare my faith (shahadah). & 5.00 \\
\hline 3 & I have a fear of doing something prohibited by Allah. & 4.81 \\
\hline 4 & When in distress, I hasten to pray (doa) to Allah. & 4.85 \\
\hline 5 & I am constantly vigilant because angels will record everything I do. & 4.56 \\
\hline 6 & I make Prophet Muhammad (pbuh) as a 'role model 'in my life. & 4.74 \\
\hline 7 & Reading historical accounts of Prophet Muhammad (pbuh) increases my love for him. & 4.82 \\
\hline 8 & Reading al-Quran brings me peace of mind. & 4.88 \\
\hline 9 & I constantly hope for Allah's mercy. & 4.81 \\
\hline 10 & I constantly work hard to achieve success. & 4.82 \\
\hline 11 & I am constantly vigilant against doing anything in violation of the Islamic law. & 4.55 \\
\hline 12 & I dislike to see male and female go out as a couple without legitimate ties (mahram). & 4.22 \\
\hline 13 & I constantly pray to Allah to forgive all my sins. & 4.87 \\
\hline 14 & I fast during Ramadan because I believe it is sinful not to. & 4.89 \\
\hline 15 & I feel peaceful when doing obligatory prayers (solah). & 4.90 \\
\hline
\end{tabular}

Source: Questionnaire 2011

Analysis of respondent's aqidah practice shows that all respondents (100.0 per cent) are at high score level. This shows that the course Islamic Education has a good effect on Islamic practice in the aspect of aqidah. This finding is supported by findings of research interviews conducted. According to a lecturer of the course, none of the PUO students has done anything which would revoke or taint his aqidah (Mohd Azrul Jaafar, 2011).

Table 3. Level of Respondents' Aqidah Practice

\begin{tabular}{ccccc}
\hline & Level & Score & N & Percent \\
\hline \multirow{4}{*}{ Aqidah } & High & $55-75$ & 100 & 100.0 \\
& Average & $35-54$ & - & - \\
& Low & $15-34$ & - & - \\
& Total & 100 & 100.0 \\
\hline
\end{tabular}

Source: Questionnaire 2011

\section{Respondent's Practice of Ibadah (Worship)}

Research findings of respondents' ibadah practice are displayed in Table 4 below. The lowest mean score is 3.81 while the highest is 4.79 and all items are at a high level of mean score.

Table 4. Respondents' Ibadah Practice

\begin{tabular}{lll}
\hline No. & Item & Mean \\
\hline 1 & I perform the obligatory prayers five times a day. & 4.15 \\
2 & I do the obligatory prayers five times a day wherever I may be. & 4.05 \\
3 & I perform the obligatory prayers on time or early. & 3.81 \\
\hline
\end{tabular}




\begin{tabular}{lll}
\hline 4 & I do not skip obligatory prayers even if pressed for time for class. & 3.99 \\
5 & I fast during the month of Ramadan. & 4.79 \\
6 & I never skip fasting in Ramadan without legitimate excuse. & 4.49 \\
7 & I make sure to pay fitrah zakah (annual head tax). & 4.66 \\
8 & I take the obligatory bath when there are signs of major impurities (hadath). & 4.77 \\
9 & I supplicate (doa) to Allah after every prayer. & 4.78 \\
10 & I always perform the sunnah which may me bring merit ( for example, sunnah prayer and & 4.53 \\
& fasting, charity, zikir, reading al-Quran) & 4.76 \\
11 & I always ensure that the food I eat is halal (lawful). & 4.43 \\
12 & I always cover my aurat wherever I go. & 4.13 \\
13 & I dislike watching television shows which reveal aurat. & 4.68 \\
14 & I read 'Bismillah' (In the name of Allah) before eating. & 4.68 \\
15 & I make an effort to know Islamic law more in depth.
\end{tabular}

Source: Questionnaire 2011

In the context of this study, ibadah practice highlighted as obligatory in the daily life of a Muslim student include the obligatory five times daily prayer, fasting in Ramadan, paying zakah, cleansing from impurities and covering the aurat. The item with the highest mean score is fasting in Ramadan (4.79), obligatory bath (4.77), reading Bismillah before eating or drinking (4.68) and knowing Islamic law more in-depth (4.68). And the lowest mean score is performing daily obligatory prayers on time or early (3.81). This means that most students do not perform obligatory prayers on time or early.

This finding is supported by outcome of interview with a lecturer who states that there are PUO students who do not perform their obligatory five times daily prayers (Ruslinawati, 2011). Based on observation during study recess from 1.15 to $2.15 \mathrm{pm}$. at the PUO mosque, there are many female students in the mosque, praying Zuhur or resting. But not many male students are in the mosque during this time. Many of the students also return home or to the hostel at this time. According to Azhar (2006) the young generation of today face a problem in being consistent with their obligatory five times daily prayers (Azhar, 2006).

Analysis of the overall level of ibadah practice is as in Table 5. Research findings show 94.0 per cent of respondents are at a high level of ibadah practice, 6.0 per cent of respondents are at average level and none of the respondents are at a low level of ibadah practice. This shows that on the whole the level of ibadah practice of the majority of respondents (94 percent) is high.

Table 5. Level of Respondents' Ibadah Practice

\begin{tabular}{ccccc}
\hline & Level & Score & N & Per cent \\
\hline & High & $55-75$ & 94 & 94.0 \\
Ibadah & Average & $35-54$ & 6 & 6.0 \\
& Low & $15-34$ & - & - \\
& & Total & 100 & 100.0 \\
\hline
\end{tabular}

Source: Questionnaire 2011

\section{Respondents' Akhlak Practice}

Research findings show respondents' akhlak practice in Table 6 . The highest mean score is 4.69 while the lowest mean scoere is 4.18 . This shows that the mean score for every item is at the high mean level. The highest mean score is doing well for others (4.67), invoking blessings for the Prophet (pbuh) (4.66) and watching one's words (4.69). And the lowest mean score is going out as a couple with a lover (4.18). Research outcome shows that the course Islamic Education has a good effect in terms of student moral character.

Analysis of the level of akhlak practice shows 96.0 percent which represent 96 respondents is at a high score 
level and only 4.0 percent representing 4 respondents is at average level of akhlak practice. And none of the respondents 0.0 per cent is at a low level of akhlak practice. This finding is in line with the interview outcome with a lecturer, according to whom; the students on the whole behave well towards the lecturer (Wan Muhammad Hafiz, 2011). Even though there are students who may do something contradicting the values of Islamic akhlak, they are but few in number.

Table 6. Respondent's Akhlak Practice

\begin{tabular}{llr}
\hline No. & Item & Mean \\
\hline 1 & I seek Allah's pleasure by doing well to others. & 4.67 \\
2 & Whenever I hear someone invoke blessings for the Prophet (pbuh), I immediately respond to it. & 4.66 \\
3 & I constantly watch my words when talking to my parents. & 4.69 \\
4 & I always give salam greetings when meeting my teacher. & 4.58 \\
5 & I make haste to help others in need. & 4.62 \\
6 & I watch my conduct so as not to offend others. & 4.51 \\
7 & I am open to accepting other's criticism to correct me. & 4.58 \\
8 & I do not get easily angry in difficult situations. & 4.41 \\
9 & I like showing good conduct. & 4.61 \\
10 & When I give or help someone, I do it without expecting anything in return. \\
11 & I would not take someone's possessions without asking for permission first. & 4.57 \\
12 & I do not feel happy when going out with my steady as a couple. & 4.57 \\
13 & If a friend borrows my money, it is not ethical for me to ask for more in repayment. & 4.18 \\
14 & I would rightaway apologise if I did something wrong. \\
15 & I always tell the truth. & 4.56 \\
\hline
\end{tabular}

Source: Questionnaire 2011

Table 7. Distribution of Respondents'Akhlak Practice Levels

\begin{tabular}{ccccc}
\hline & Level & Score & N & Percentage \\
\hline \multirow{2}{*}{ Akhlak } & High & $55-75$ & 96 & 96.0 \\
& Average & $35-54$ & 4 & 4.0 \\
& Low & $15-34$ & - & - \\
& & Total & 100 & 100.0 \\
\hline
\end{tabular}

Source: Questionnaire 2011

\section{Overall Level of Respondents' Islamic Practice}

Table 8. Distribution of Respondents' Level of Islamic Practice

\begin{tabular}{ccccc}
\hline & Level & Score & N & \% \\
\hline \multirow{2}{*}{ Overall } & High & $166-225$ & 98 & 98.0 \\
Islamic Practice & Average & $106-165$ & 2 & 2.0 \\
& Low & $45-105$ & - & - \\
& & Total & 100 & 100.0 \\
\hline
\end{tabular}

Source: Questionnaire 2011 
Analysis outcome of the overall level of Islamic practice researched in terms of akidah, ibadah dan akhlak is showed in Table 8. Research findings show that 98.0 per cent of respondents have a high score of Islamic practice and only 2 per cent of respondents have an average score. And none of the respondents, 0.0 percent is at a low level of Islamic practice. This means that the overall level of respondents' Islamic practice in the three aspects of aqidah, ibadah and akhlak is high, 98 percent this shows that on the whole, the Islamic Education course taken by the students for 2 semesters has a favourable effect on the Islamic practice of Muslim students.

Outcome of interview with lecturers state the overall Islamic practice among PUO students is good (Jamayah, 2011). Through the researcher's observation of the PUO campus environment, Islamic practice among students is good and no students have been found to act openly against Islamic teachings.

\section{Discussion}

Research findings show that the level of Islamic practice of PUO students in the three aspects (aqidah, ibadah, akhlak) is high. This high level achievement is due to the factor of respondents having attended the Islamic Education course for two semesters. The course contents emphasize theoretical and practical aspects for a period of 30 lecture hours (15 hours of theory and 15 hours of practical) per semester. These research findings are similar to study findings of Islamic Education curriculum at polytechnic level in Malaysia by Ahmad Mohd Salleh (1990). His research finds that the curriculum implemented then achieved its objectives because 90.0 per cent of respondents understood the teachings imparted and 68.6 per cent of respondents stated Islamic Education as the course they had most interest in while 96.2 per cent of respondents stated that the syllabus suited student capability (Ahmad, 1990).

Data shows that practice of aqidah is the highest in comparison to ibadah and akhlak. This means that students keep their belief or aqidah practices. In Islam, aqidah is the most important aspect in all practice. This is stressed by al-Ghazali (2000) who stated that aqidah and faith are the most honorable or noble matters in Islamic teachings and source of all goodness (al-Ghazali, 2000). Aqidah means complete belief or faith in the truth or reality, without doubt, as prescribed by Islam (al-Jaza'iri, without date). This is the reason students have a high level of aqidah practice because they understand the importance of aqidah for a Muslim. This finding is in line with the research finding by Alias (2010) which is related to the Evaluation of Curriculum Implementation in Polytechnic Islamic Education, Ministry of Higher Education, Malaysia. His research shows that level of the behavior of Polytechnic students in terms of aqidah is high whereas it is average in terms of ibadah and akhlak (Alias, 2010).

The interesting thing about this research outcome is that students have almost the same level of practice in terms of akhlak and ibadah, that is, 94.0 percent of respondents are at a high level of ibadah practice, 6.0 percent of respondents have an average level of ibadah practice and none ( 0.0 percent) at a low level. And 96.0 percent which represent 96 respondents are at a high score level of akhlak practice and only 4.0 percent which represent 4 respondents are at an average level, and none ( 0.0 percent) at the low level of akhlak practice. This shows that ibadah practice influences student behavior. The higher the ibadah practice, the better their akhlak. This is proven in a study by Asmahan (2009). The purpose of performing specific ibadah in Islam such as prayers, reading al-Quran, fasting in Ramadan, paying zakah and performing Haj are not merely requirements of Islamic teachings, but also to improve moral character and behavior. According to Abdul Karim Zaydan (1972), each thing done by a Muslim in his life in compliance with Allah's command is considered as ibadah and purification of his or her soul. Hence, akhlak is closely linked with implementation of the ibadah aspect because a sound akhlak will lead to doing well and leaving that which is prohibited by God (Ibn Taimiyyah 1981, Zakaria, 2001).

This discussion explains that akhlak is among that which cannot be neglected in the life of a student. The Prophet (pbuh) was deeply concerned about the importance of an honourable character as stated in a hadith:

"There is nothing which outweighs more on a weighing scale than an honourable character and one with such a character may achieve the rank of he who fasts and prays " (al-Tirmidhi, Kitab (23) al-Bir wa al-Silah, Bab (60) ma Ja'a fi al-Husn al-Khuluq)

This explains that all knowledge learnt would be meaningless if it were not applied in life. A learned person who does not practise his knowledge would find it difficult to attain happiness because as al-Ghazali (2000) stated, true happiness is part of happiness achieved through al-nafsiyyah factor such as knowledge (especially gnosis of Allah s.w.t) and practice which comprise of ibadah and honourable character(al-Ghazali,2000). It also explains that the relationship of these three aspects is very crucial in a person's life. Al-Ghazali (2000) concludes that an honourable character is half of religion and training for those who practise ibadah.

\section{Conclusion}


Islamic teachings which is contained in the Qur'an and Sunnah are to be practiced by Muslims themselves.There are three aspects of the teachings in Islam that need to be practiced, which is aqidah (belief), ibadah (worship) and akhlak (moral character). In the context of research, sometimes it is difficult to measure the level of one's religious practices. With the establishment of the Islamic Educational it can measure the level of religious practice among the adolescents. There will be more in-depth research and several measurement instruments could be developed further and use in the field of Islamic studies. Analysis of respondent's aqidah practice shows that all respondents (100.0 per cent) are at high score level. Meanwhile, research findings about the level of ibadah practice, show 94.0 per cent of respondents are at a high level of ibadah practice. This shows that on the whole the level of ibadah practice of the majority of respondents (94 percent) is high. The level of akhlak practice shows 96.0 percent which represent 96 respondents is at a high score level. Outcome of the overall level of Islamic practice researched in terms of aqidah, ibadah and akhlak is showed that 98.0 per cent of respondents have a high score of Islamic practice. This finding shows that the course Islamic Education has a good effect on Islamic practice in the aspect of aqidah, ibadah and akhlak. Finally, this research finds that some improvement of the curriculum is required to improve the level of religious practice among youth. This research suggests that the syllabus of Islamic education implemented in the polytechnic stress more on practical sessions, especially in specific ibadah exercises and morals/ character in daily life. Practical sessions or hands-on learning suit the objectives of Islamic education as a form of Islamic practice among students and is suitable for technical stream students who are more exposed to teaching and learning through the hands-on method. In addition, it is suggested that the akhlak aspect be part of the marking scheme as the objectives of Islamic Education is not only to produce knowledgeable practising students but also to nurture a suitably Islamic student character. It is suggested that drafters of the Islamic Education curriculum should not only measure the knowledge aspect of students since secondary school days, but more importantly, use reinforcement on students to practise Islamic teachings throughout their lives.

\section{Acknowledgements}

This research received a grant from Research University(GUP), University Kebangsaan Malaysia.Project Code(UKM-GUP-TKS-07-08-076).

\section{References}

Ahmad, A. bin. (2006). Teaching strategy Self Arrangement of Islamic education and appreciation of the character of secondary school students in Sarawak (Unpublished PhD's thesis). The National University of Malaysia, Selangor, Malaysia.

Ahmad, R. (2011). Lecturer. Interview, 20 Januari 2011.

al-Ghazali, A. H., \& Ahmad, M. B. (2000). Ihya' 'Ulum al-Din. Kaherah: Dar al-Taqwa li al-Turath.

Al-Jaza'iri, Abu Bakr Jabar. (n. d.). Aqidah al-Mu'min. Qaherah: Dar al-Kutub al-Salafiyah.

Al-Tirmidhi, Abi 'Isa Muhammad bin 'Isa Bin Surah. (2004). Sunan al-Tirmidhi. Kaherah: Dar Ibn Haitham.

Daradjat, Z. (1992). The Islamic Education Science. Jakarta: Bumi Aksara.

Fadzil, S. M. M. (2011). Lecterur. Interview, 28 Jun 2011.

Ghani, R. A. (2011). Lecturer. Interview, 28 Jun 2011.

Hamjah, S. H., Rasit, R. M., Samuri, M. Al-A., Sham, F. M., Ismail, Z., \& Kusrin, Z. M. (2014). The Role of the Muslim Family in Dealing with Adolescent Out of Wedlock Pregnancy. Mediterranean Journal of Social Sciences, 5(29), 101-106. http://dx.doi.org/10.5901/mjss.2014.v5n29p101

Hussin, J. (2011). Lecturer. Interview, 30 Jun 2011.

Hussin, Z. (1997). The purposes of the pattern of appearance of new textbooks of Islamic Education. Journal of Education, 20. Kuala Lumpur.

Ibn Taimiyyah, Taqiy al-Din Ahmad Ibn Abd al-Halim. (1981). al-Ubudiyyah.Beirut:Dar al-Kutub al-Ilmiyyah.

Ihsan, A. D. bin H. (1995). Appreciation of the Value of Morality in Islamic Education among Trainee Islam Maktab Perguruan Teknik (MPT) Kuala Lumpur (Unpublished Master's thesis). The National University of Malaysia, Selangor, Malaysia.

Ismail, A. M. bin. (2009). The influence of Faith on the appreciation of National morals among high school students in Malaysia (Unpublished PhD's thesis). The National University of Malaysia, Selangor, Malaysia.

Jaafar, A. M. (2011). Lecturer. Interview, 30 Jun 2011. 
Jaafar, M. A. (2011). Lenturer, Interview, 31 Jun 2011.

Latif, S. A. (1990). Islamic education courses in Politeknik Ungku Omar: A review of the curriculum Towards Achieving (Unpublished Master's thesis). The National University of Malaysia, Selangor, Malaysia.

Majid, F. bin A. (2003). The influence of family environment and schools against the appreciation of Islam Students: case studies of Students of Sekolah Menengah Kebangsaan Sri Serdang (Unpublished Master's thesis), The National University of Malaysia, Selangor, Malaysia.

Mohd @ Mohamed b Mohamed Zin. (2000). The factors of Islamic Practice at Institute Study of high private (IPTS) Technical (Unpublished Master's disertation). The National University of Malaysia, Selangor, Malaysia.

Mokhtar, A. binti. (2009). The practice of the teachings of Islam among the Teenage Sultan Azlan Shah Polytechnic, Behrang, Perak (Unpublished Master's thesis). The National University of Malaysia, Selangor, Malaysia.

Mustafa, A. (1999). History of Islami Education in Indonesia. Bandung: CV Pustaka Setia.

Report on The Development and evaluation of curriculum, Ministry of higher education in Malaysia. (2010). Putrajaya: JPTKPTM.

Saad, A. M. (2010). Assessment of the Implementation of Islamic Education Curriculum of Polytechnical, Ministry of Higher Education in Malaysia (Unpublished PhD's thesis). The National University of Malaysia, Selangor, Malaysia.

Sabiq, al-S. (1992). al-Aqa'id al-Islamiyyah. Beirut: Dar al-Fikr.

Salleh, A. M. (1990). Islamic Education curriculum polytechnics in Malaysia: An Analysis (Unpublished Master's thesis). Universiti Malaya, Kuala Lumpur, Malaysia.

Sham, F. M. (2015). Stress Symptoms Among Adolescent: A Study from Islamic Perspective. Journal of Religion \& Health, 54(4), 1278-1285. http://doi.org/10.1007/s10943-014-9866-7

Sham, F. M., Tibek, S. R., Mastor, K. A., Yunus, A. R. M., Ismail, Z., \& Hamjah, S. H. (2011). Research Report, Islamic Practice Instrument for Adolescence. Bangi: Universiti Kebangsaan Malaysia.

Stapa, Z. (2001). Akidah and Akhlak in life of Muslim. Kuala Lumpur: Utusan Publication \& Distributors Sdn.Bhd.

Wan Mohamamad Hafiz Wan Mat Resab. (2011). Lecturer, Interview, 28 Jun 2011.

Yasin, M. S. (1986). Aqidah Muslim. Bandar Baru Bangi: Pustaka al-Hikmah.

Zaydan, A. K. (1972). Usul al-Da'wah. Baghdad:Salman al-A'zami.

\section{Copyrights}

Copyright for this article is retained by the author(s), with first publication rights granted to the journal.

This is an open-access article distributed under the terms and conditions of the Creative Commons Attribution license (http://creativecommons.org/licenses/by/3.0/). 